\title{
McVie calls for reduction in cancer charity numbers
}

Britain has too many cancer research charities, with the result that funds donated by the public for research are not being used as effectively as they could be, according to Gordon McVie, the head of one of the largest such bodies, the Cancer Research Campaign (CRC).

In a speech last month that triggered a heated debate over the best way to distribute the estimated $£ 135$ million per year privately donated to cancer research through about 600 charities, $\mathrm{McVie}$ argued for a change in the law to avoid the inefficient use of funds. In particular, he wants Charity Commissioners to have the

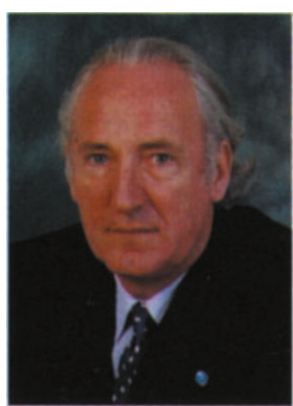

Gordon McVie nization finding itself having to fight increasingly hard to secure public support in the face of smaller competitors. "Our experience is that if people who give money live here, they want the money to be spent authority to judge whether a body seeking charitable status in order to raise funds for research is likely to duplicate work already being done by others. At present, commissioners are only required to evaluate whether such an organization meets the criteria characterizing its activities as charitable.

McVie's concerns are endorsed by Paul Nurse, director-general of Britain's other large cancer research organization, the Imperial Cancer Research Fund (ICRF). "The effective co-ordination of cancer research across the country is made more complex by the proliferation of small charities and these small organizations can sometimes find it difficult to obtain the high quality advice they need from external experts," says Nurse. Keen to demonstrate their own desire to avoid duplication, the CRC and the ICRF-often seen as determined rivals in fund raising - have for the first time agreed to spend money on joint projects.

But smaller charities who argue that their independence gives them a flexibility in research funding that larger bodies lack, gave a cool response. "I do not think that small equates with inefficient," says Barbara Goldberg, director of the Breast Cancer Campaign. Although Goldberg's annual research budget is about one-hundredth that of the CRC, she argues that it can still fund research effectively by identifying specific needs. "We are going for small niches, for example transitional research that involves spotting things that look interesting in the laboratory and taking them to the clinic," she says.

Some, particularly those whose activities are regional, are openly wary of what they see as a possible takeover bid by a large orgahere," says Sally Crerar, chief fund raiser for Yorskshire Cancer Research. Crerar's organization raises around $£ 4$ million a year which is used to support research at five university teaching hospitals in the county of Yorkshire.

McVie denies that he has any plans to launch a hostile take-over of smaller organizations. "All we want to achieve is some common sense, and to get the maxi-

"skimping" on ensuring that applications for funding are subject to "proper scientific peer review." In particular, he expresses concern at finding projects rejected for funding by the CRC on grounds of quality being subsequently financed by smaller organizations. Both the ICRF and the CRC are now offering to assist smaller charities with the peer review process.

McVie wants a dramatic reduction in the number of separate charities, suggesting that the optimal number would be "between about 6 and a maximum of 12." But he acknowledges that, given the determinedness with which many of the smaller groups defend their autonomy, such a change is unlikely to occur. A more viable goal may be to persuade individuals keen to support a particular line of cancer research to do so through one of the larger charities.

David Dickson, LoNDON

\section{A tale of two cancer drugs}

It seemed too good to be true. And, ultimately, it was. For a few chaotic days, a story prominently displayed on the front page of the normally restrained New York Times prompted a public frenzy among cancer patients, researchers and the media.

The piece, written by Gina Kolata, one of the paper's medical/science reporters, trumpeted the awesome potential of a pair of experimental cancer-starving drugs that had worked miracles in mice, eliminating tumors by cutting off their blood supply and with virtually no side effects. And if that wasn't enough, the story quoted Nobel Prize winner James Watson as saying the drugs' creator, Harvard Medical School's Judah Folkman, "is going to cure cancer in two years."

The resulting hoopla prompted desperate cancer patients across the country to plead with their oncologists for this remarkable new therapy; sent the share price of EntreMedthe small biotech company developing the drugs angiostatin and endostatin - soaring; and as these things so often do, pressured other media into a blitz of copy-cat stories reporting this dramatic "breakthrough."

Never mind that this was old news: the results already had been published (Nature, $390 ; 404,1997)$, reported at scientific meetings and had even appeared months earlier in the New York Times itself. And never mind that nothing had happened recently to advance the story - the drugs were still being tested in mice and versions have not yet been developed for use in humans. The latest story appeared to stem soley from Kolata's reporting of a dinner party conversation that included James Watson. In the aftermath of the story, Watson claimed in a letter to the Times that he had been misquoted.

To make matters worse, it was also revealed that Kolata-just around the time her story was burgeoning into an uproar-had been circulating a book proposal about the research among several publishers - a proposal she hastily withdrew.

Cancer treatment is rife with stories of preliminary research curing the disease in animals with drugs that eventually fail or prove less effective in humans and the whole unfortunate episode has again raised troubling questions of how the media report news of early stage medical advances. Nearly every week, researchers report on new compounds that kill viruses in the test tube, or cure cancer in the mouse. Most experienced medical journalists are aware that the journey from the laboratory to humans is a long and painstaking one that is all too often fraught with disappointment and temper their reporting accordingly. Most, but apparently not all.

Marlene Cimons, Washington, D.C. 